\title{
Comparative Phytochemical Constituents and Antioxidant Activity of Wild and Cultivated Alepidea amatymbica Eckl \& Zeyh
}

\author{
Ramatsobane Maureen Mangoale (i) and Anthony Jide Afolayan \\ Medicinal Plants and Economic Development (MPED) Research Centre, Department of Botany, University of Fort Hare, \\ Alice 5700, South Africa \\ Correspondence should be addressed to Anthony Jide Afolayan; aafolayan@ufh.ac.za
}

Received 14 October 2019; Revised 24 February 2020; Accepted 12 March 2020; Published 13 April 2020

Academic Editor: Anna Chiarini

Copyright ( 2020 Ramatsobane Maureen Mangoale and Anthony Jide Afolayan. This is an open access article distributed under the Creative Commons Attribution License, which permits unrestricted use, distribution, and reproduction in any medium, provided the original work is properly cited.

\begin{abstract}
There is a need to scientifically validate the claim that wild species of medicinal plants are more potent than the cultivated plants. Thus, this study evaluated the phytochemical and antioxidant properties of wild and cultivated Alepidea amatymbica. Acetone, methanol, and water extracts of the rhizome of wild and cultivated A. amatymbica were evaluated for total phenol, flavonol, flavonoid, tannin, proanthocyanidin, saponin, and alkaloid contents using spectrophotometric methods. In vitro antioxidant activity was measured using 2,2-diphenyl-1-picrylhydrazyl (DPPH), 2,2' -azino-bis(3-ethylbenzothiazoline)-6-sulfonic acid (ABTS), ferric reducing antioxidant power (FRAP), nitric oxide (NO), and hydrogen peroxide assays. The wild extracts had higher phytochemical contents in most of the assays than cultivated extracts. Total phenol in the wild extracts ranged from 32.30 to $117.8 \mathrm{mg} \mathrm{GAE} / \mathrm{g}$ with the acetone extracts having the highest content while the water extracts were the least. The range in the total phenol of the cultivated species was 66.46 to $98.44 \mathrm{mg} \mathrm{GAE} / \mathrm{g}$ with the methanol extracts having the highest content while water extracts was the least. The flavonoid content ranged from 55.01 to $99.09 \mathrm{mg} \mathrm{QE} / \mathrm{g}$ and from 48.65 to $67.32 \mathrm{mg} \mathrm{QE} / \mathrm{g}$ for the wild and cultivated plants, respectively. The alkaloid contents ranged from 14.70 to $17.80 \%$ in the wild species while it ranged from 11.98 to $13.21 \%$ in the cultivated species. The wild species also showed higher antioxidant activities in most of the assays evaluated. This study has implications for both pharmacological and conservation purposes.
\end{abstract}

\section{Introduction}

The rhizomes of Alepidea amatymbica are widely used for the treatment of various diseases because of their effectiveness due to the presence of the bioactive compounds. Some of the phytochemicals isolated from dried rhizome of A. amatymbica include dehydro-16-kaurene-19-oic acid, ent-16-kauren-19oic acid, wedelia seco-kaurenolide, 313-acetoxy, phenolic acid, and rosmarinic acid [1]. Phytochemical compounds such as phenolic acid and flavonoids have health benefits, and they are an important part of human diet [2]. These compounds have been reported in many studies as free radical scavengers against superoxide, lipid peroxyl, and hydroxyl radicals [3-5]. This, therefore, highlights many of their health-promoting functions as well as the prevention of diseases associated with oxidative damage of membranes, proteins, and deoxyribonucleic acid (DNA) [6]. The amount of polyphenolic constituents present in the plant affects its antioxidant activities [7]. Antioxidants are potential scavengers of free radicals in the body and protect the body against ill health and ravages of aging [8]. The use of natural antioxidants from plants has gained much attention as they are believed to be safer and have greater therapeutic activity than synthetic antioxidants [9].

According to the International Union for Conservation of Nature and Natural Resources (IUCN) red data list criteria of South Africa, A. amatymbica is considered vulnerable and under conservation in protected areas [10]. It is mostly harvested for medicinal purposes and is used as antibacterial, antifungal, anti-inflammatory, antihypertensive, anti-HIV, and diuretic agents [1]. It is overexploited, as it is commonly harvested for commercial purposes and sold in traditional markets [11]. The collection and trading of the plant products provide additional income for the rural poor people but, 
however, may result in overexploitation which could lead to its extinction [12].

Domestication of medicinal plants offers an excellent means of halting overexploitation [13]. As a conservation approach, ex situ cultivation is becoming a key element of modern conservation strategies [14]. Unfortunately, medicinal plant users perceive cultivated plants as less potent compared to wild ones [15], and lack of scientific evidence on the potency of cultivated medicinal plants remains a limiting factor. It is also reported that domestication of wild plants has to be done with extreme care because they may fail to synthesize the bioactive constituents following relocation [16]. Several studies have reported that the majority of pharmacologically important plant compounds are produced during defense mechanism when plants are subjected to stress and other secondary metabolites are produced due to the ability of plants to respond to chemical and physical stimuli $[17,18]$. According to Bairu et al. [19], plants that are growing outside their natural environments will thus not produce desired bioactive compounds; hence, there is a need to evaluate this claim. Zheng et al. [20] also reported that the amount of phytochemicals in plants varies considerably from different ecological and climatic environments. No previous studies have been performed on the antioxidant and biological activities of Alepidea amatymbica grown in the wild and under cultivated conditions. Therefore, this study evaluated and compared phytochemical and antioxidant activity of the wild and cultivated A. amatymbica. The result of the study can provide useful information about the suitability of cultivated A. amatymbica rhizome as an alternative to wild species in terms of bioactive compounds.

\section{Material and Methods}

2.1. Collection and Preparation of Plant Material. The wild rhizome of $A$. amatymbica was obtained from its natural habitat in Emnyameni village ( $\left.32^{\circ} 34^{\prime} 17.39^{\prime \prime} \mathrm{S} ; 27^{\circ} 6^{\prime} 55.16^{\prime \prime} \mathrm{E}\right)$ in the Keiskammahoek area of the Eastern Cape Province, South Africa, in May 2014. The vegetation type is Amathole Montana grassland [21]. The cultivation of the plant was carried out in a greenhouse until flowering (May-December 2014) at Fort Cox College of Agriculture and Forestry. The rhizomes from both wild and cultivated A. amatymbica were collected at the flowering stage. Plants were authenticated at the Department of Botany in the University of Fort Hare, and voucher specimens Mau2015/04 and Mau2015/05 were deposited at the Giffen Herbarium of the university.

2.2. Reagents Used. The reagents used are as follows: methanol, acetone, aluminum chloride $\left(\mathrm{AlCl}_{3}\right)$, quercetin dehydrate, tannic acid, Folin-Ciocalteu, sodium carbonate $\left(\mathrm{Na}_{2} \mathrm{CO}_{3}\right)$, hydrochloric acid (HCL), diethyl ether, butanol, sodium chloride, vanillin, ammonium hydroxide $\left(\mathrm{NH}_{4}(\mathrm{OH})_{2}\right)$, azino-bis(3-ethylbenzthiazoline)-6-sulphonic acid (ABTS), 2,2-diphenyl-1-picrylhydrazyl (DPPH) radical scavenging activity, potassium persulfate, vitamin $\mathrm{C}$, butylated hydroxytoluene $(\mathrm{BHT})$, potassium ferricyanide $\left(\mathrm{K}_{3} \mathrm{Fe}(\mathrm{CN})_{6}\right.$, trichloroacetic acid, ferrous chloride $(\mathrm{FeCl})_{3}$, sodium nitroprusside, sulfonic acid, naphthylethylene diamine dichloride, acetic acid, ascorbic acid, butylated hydroxyl toluene, rutin, and hydrogen peroxide $\left(\mathrm{H}_{2} \mathrm{O}_{2}\right)$. The chemicals used for this study were of standard grade purchased from Merck and SigmaAldrich (Gauteng Province, South Africa). Chemicals mentioned above were of analytical grade.

2.3. Preparation of the Plant Extracts. The rhizomes from wild and cultivated plants were rinsed with deionized water to remove soil particles and gently blotted with paper towel to remove water before chopping using a sterilized kitchen grater. Portions of grated wild and cultivated fresh A. amatymbica (200 g) were separately extracted in different solvents (acetone, water, and methanol) on an orbital shaker (Stuart Scientific Orbital SOI, Essex) for 24 hours. Each extract was filtered using a Buchner funnel and Whatman No. 1 filter paper. Water extract was frozen at $40^{\circ} \mathrm{C}$ and concentrated using a freeze dryer (VirTis BenchTop K, VirTis Co., Gardiner, NY) for 48 hours. Acetone and methanol extracts were concentrated to dryness under reduced pressure using rotary evaporator (Strike 202, Steroglass, Italy). Each extract was subsequently reconstituted in its solvent of extraction to give desired concentrations used for the various analyses.

\subsection{Qualitative Phytochemical Screening}

2.4.1. Determination of Total Phenols. Total phenol content was determined using the Folin-Ciocalteu method described by Oyedemi et al. [22] using tannic acid as standard. Half a millilitre $(0.5 \mathrm{~mL})$ of the extracts $(1 \mathrm{mg} / \mathrm{mL})$ was mixed with $2.5 \mathrm{~mL}$ of $10 \%$ Folin-Ciocalteu solution and $2 \mathrm{~mL}$ of $\mathrm{Na}_{2} \mathrm{CO}_{3}$ $(75 \% \mathrm{w} / \mathrm{v})$. The mixture was vortexed for 30 seconds, and the resulting mixture was incubated at $40^{\circ} \mathrm{C}$ for 30 minutes for color development. Absorbance was measured at $765 \mathrm{~nm}$ using a UV spectrophotometer (AJI-CO 3 UV-VIS). The total phenolic content of the sample was extrapolated from as $\mathrm{mg} / \mathrm{g}$ of gallic acid standard (mg GAE/g) using the following derived equation based on the calibration curve of the standard: $Y=8.773 x+0.1956\left(R^{2}=0.9965\right)$, where $x$ is the absorbance and $Y$ is the gallic acid equivalent (mg GAE/g). $\mathrm{mg} \mathrm{GAE} / \mathrm{g}$ is derived from the equation $C V / m$, where " $C$ " is the concentration as derived from the calibration curve equation in $\mathrm{mg} / \mathrm{mL}$, " $V$ " is the volume of the extract used in the assay in $\mathrm{mL}$, and " $m$ " is the mass of the extract used in the assay in "g."

2.4.2. Determination of Total Flavonoids. Total flavonoids in A. amatymbica were quantified using the method of Arjamand et al. [23]. Half a millilitre $(0.5 \mathrm{~mL})$ of $2 \% \mathrm{AlCl}_{3}$ in ethanol was added to $0.5 \mathrm{~mL}(1 \mathrm{mg} / \mathrm{mL})$ of the sample solution and incubated for 1 hour at room temperature, after which the absorbance was measured at $420 \mathrm{~nm}$. The extracted sample was evaluated at a final concentration of $0.1 \mathrm{mg} / \mathrm{mL}$, and the flavonoid content was calculated as quercetin $(\mathrm{mg} / \mathrm{g})$ equivalents using the following equation based on the calibration curve: $Y=0.025 x+0.1335\left(R^{2}=0.9812\right)$, and expressed as $\mathrm{mg}$ of quercetin equivalent $(\mathrm{QE} / \mathrm{g})$.

2.4.3. Determination of Total Flavonols. Total flavonol content was estimated using the method of Mbabie et al. [24]. Two millilitres $(2 \mathrm{~mL})$ of plant extracts $(1 \mathrm{mg} / \mathrm{mL})$ was mixed 
with $2 \mathrm{~mL}$ of $\mathrm{AlCl}_{3}$ prepared in ethanol and $3 \mathrm{~mL}$ of $50 \mathrm{~g} / \mathrm{L}$ sodium acetate solution. The absorption at $440 \mathrm{~nm}$ was measured after 2.5 -hour incubation at $20^{\circ} \mathrm{C}$. The total flavonol content was calculated as quercetin $(\mathrm{mg} / \mathrm{g})$ using the derived equation based on the calibration curve $Y=0.0255 x$ $\left(R^{2}=0.9812\right)$, where $Y$ is the quercetin equivalent ( $\mathrm{mg}$ $\mathrm{QE} / \mathrm{g}$ ) and $x$ is the absorbance. The formula used was $C V / m$, as described above for total phenols.

2.4.4. Determination of Total Proanthocyanidin. Total proanthocyanidin was estimated as described by Kibiti and Afolayan [3]. Half a millilitre of $0.1 \mathrm{mg} / \mathrm{mL}$ of extract solution was mixed with $3 \mathrm{~mL}$ of $4 \%$ vanillin-methanol solution and $1.5 \mathrm{~mL}$ hydrochloric acid (HCL) and vortexed. The resulting mixture was allowed to stand for 15 minutes at room temperature followed by the measurement of the absorbance at $500 \mathrm{~nm}$. The experiment was done in triplicate. Proanthocyanidin content was evaluated using the calibration curve equation: $Y=0.9038 x+0.0449\left(R^{2}=0.9951\right)$, and was expressed as $\mathrm{mg}$ catechin equivalent $(\mathrm{CE}) / \mathrm{g}$ using the formula from the equation $C V / m$, where " $C$ " is the concentration as derived from the calibration curve equation in $\mathrm{mg} / \mathrm{mL}$, " $V$ " is the volume of the extract used in the assay in $\mathrm{mL}$, and " $m$ " is the mass of the extract used in the assay in " $\mathrm{g}$ ".

2.4.5. Determination of Total Tannin Content. Tannin content was estimated according to Sowunmi and Afolayan [4] with slight modifications. $0.20 \mathrm{~g}$ of the sample was added to $20 \mathrm{~mL}$ of $50 \%$ methanol. This mixture was shaken thoroughly and placed in a water bath at $80^{\circ} \mathrm{C}$ for 1 hour to ensure uniform mixing. The extract was filtered into a $100 \mathrm{~mL}$ volumetric flask, followed by the addition of $20 \mathrm{~mL}$ distilled water, $2.5 \mathrm{~mL}$ Folin-Ciocalteu reagent, and $10 \mathrm{~mL}$ of $17 \%$ aqueous $\mathrm{Na}_{2} \mathrm{CO}_{3}$. The mixture was made up to $100 \mathrm{~mL}$ with distilled water and allowed to stand for 20 minutes. The development of a bluish green color was observed at the end of the reaction mixture of the different concentration ranges from 0 to $10 \mathrm{ppm}$. The absorbance of the tannic acid standard solutions as well as the sample was measured at $760 \mathrm{~nm}$. Results were expressed as $\mathrm{mg} / \mathrm{g}$ of tannic acid equivalent using the calibration curve: $Y=0.0593 x+0.0485\left(R^{2}=0.9826\right)$, where $x$ is the absorbance and $Y$ is the tannic acid equivalent $(\mathrm{mg} / \mathrm{g})$.

2.4.6. Determination of the Saponin Content. Saponin content was determined as described by Otunola and Afolayan [25]. Five grams of plant materials was dispersed in $50 \mathrm{~mL}$ of $20 \% v / v$ ethanol prepared in distilled water. The mixture was heated in a hot water bath at $55^{\circ} \mathrm{C}$ for 4 hours with continuous stirring. The mixture was filtered, and the residue was reextracted with another $50 \mathrm{~mL}$ of $20 \%$ aqueous ethanol. The volume was reduced to $20 \mathrm{~mL}$ in a hot water bath at $100^{\circ}$ C. The concentrate was transferred to a separating funnel, and $10 \mathrm{~mL}$ diethyl ether was added. The concentrated solution obtained was shaken vigorously in a separating funnel, and ether layer was discarded, while the aqueous layer was retained. The process was repeated twice for purification purposes, and $20 \mathrm{~mL}$ of butanol was added to the aqueous layer. The n-butanol extracts were washed twice with $10 \mathrm{~mL}$ of $5 \%$ $(w / v)$ aqueous sodium chloride, and the mixture was heated to evaporation on a hot water bath, then oven dried at $40^{\circ} \mathrm{C}$ to constant weight. The percentage saponin content of the sample was calculated using the formula

$$
\% \text { Saponin content }=\frac{\text { weight of residue }}{\text { weight of original sample }} \times 100 \text {. }
$$

2.4.7. Determination of Alkaloids. Alkaloid contents were quantitatively determined according to Olajuyigbe and Afolayan [26]. Five grams of fresh rhizome samples was soaked in $200 \mathrm{~mL}$ of $10 \%$ acetic acid in ethanol. The mixture was covered and allowed to stand for 4 hours. The filtrate was concentrated in a water bath to a quarter of its original volume. Concentrated $\mathrm{NH}_{4}(\mathrm{OH})_{2}$ was added dropwise to the filtrate until precipitation was completed, and the whole solution was allowed to settle. The collected precipitates were washed with dilute ammonium hydroxide then filtered again. The residue collected was dried and weighed. The alkaloid content was determined using the formula

$$
\text { \%alkaloid }=\frac{\text { weight of precipitate }}{\text { weight of original sample }} \times 100 \text {. }
$$

2.5. Determination of In Vitro Antioxidant Activity. The antioxidant activities of water, acetone, and methanol of cultivated and wild A. amatymbica were determined using $2,2^{\prime}$ -azino-bis(3-ethylbenzthiazoline-6-sulphonic acid (ABTS), 2,2-diphenyl-1-picrylhydrazyl (DPPH) radical scavenging activity, ferric reducing power, nitric oxide, and hydrogen peroxide inhibitory assays.

2.5.1. 2,2'-Azino-bis(3-ethylbenzthiazoline)-6-sulphonic Acid (ABTS) Radical Scavenging Assay. The method of Wintola and Afolayan [27] was adopted for the determination of ABTS activity of the plant extract. The ABTS radical was generated by allowing a mixture of $7 \mathrm{mM}$ ABTS and $2.4 \mathrm{mM}$ potassium persulfate in the same ratio to react in the dark for overnight at room temperature. The solution was then diluted by mixing $1 \mathrm{~mL}$ ABTS in $60 \mathrm{~mL}$ of methanol to obtain the absorbance of $0.706 \pm 0.001$ units at $734 \mathrm{~nm}$ using a spectrophotometer. ABTS solution was freshly prepared for the assay. One millilitre $(1 \mathrm{~mL})$ of different concentrations $(0.025,0.05,0.1,0.2$, and $0.5 \mathrm{mg} / \mathrm{mL})$ of the extracts and standard drugs was allowed to react with $1 \mathrm{~mL}$ of ABTS radical in the dark for 7 minutes. The absorbance was taken using a spectrophotometer at $734 \mathrm{~nm}$. The percentage inhibition of ABTS by the plant extract was compared with that of vitamin $\mathrm{C}$ and BHT as standards. The percentage inhibition of ABTS was calculated as

$$
\begin{aligned}
& \text { \%ABTS scavenging activity } \\
& \quad=[(\text { Abs }(\text { control })-\text { Abs }(\text { sample })) /(\text { Abs control })] \times 100 .
\end{aligned}
$$

where Abs (control) is the absorbance of ABTS+radical +methanol and Abs (sample) is the absorbance of ABTS +radical+sample extract or standard. 
2.5.2. 2,2-Diphenyl-1-picrylhydrazyl (DPPH) Radical Scavenging Activity. The scavenging activity of the plant extract against DPPH was determined according to the method described by Otang et al. [5]. A solution of $0.135 \mathrm{mM}$ DPPH in methanol was prepared, and $1 \mathrm{~mL}$ of this solution was mixed with different concentrations $(0.025,0.05$, $0.1,0.2$, and $0.5 \mathrm{mg} / \mathrm{mL}$ ) of various extracts of A. amatymbica and standard antioxidants (vitamin C and BHT). The reaction mixture was vortexed thoroughly and left in the dark at room temperature for 30 minutes and absorbance measured at $517 \mathrm{~nm}$. The ability of the plant extracts to scavenge DPPH was calculated as

\%DPPH inhibition $[($ Abs (control) - Abs ( sample $)) /($ Abs control $)] \times 100$,

where Abs (control) is the absorbance of DPPH radical +methanol and Abs (sample) is the absorbance of DPPH radical+sample extracts/standard.

2.5.3. Determination of Ferric Reducing Antioxidant Power (FRAP). The reducing power of A. amatymbica extract was evaluated according to the method described by Idris et al. [28] with a slight modification. The mixture containing $2.5 \mathrm{~mL}$ of $0.2 \mathrm{M}$ phosphate buffer (pH6.6) and $2.5 \mathrm{~mL}$ of potassium ferricyanide $\left(\mathrm{K}_{3} \mathrm{Fe}(\mathrm{CN})_{6}\right)$ (1\%) was added to $1 \mathrm{~mL}$ of each extract at different concentrations $(0.025,0.05$, $0.1,0.2$, and $0.5 \mathrm{mg} / \mathrm{mL}$ ). The mixture was incubated at $50^{\circ} \mathrm{C}$ for 20 minutes. After incubation, $2.5 \mathrm{~mL}$ of trichloroacetic acid $(10 \%)$ was added to terminate the reaction. The mixture was centrifuged at $3000 \mathrm{rpm}$ for 10 minutes. The supernatant $(2.5 \mathrm{~mL})$ was collected, and it was mixed with distilled water $(2.5 \mathrm{~mL})$ and $0.5 \mathrm{~mL} \mathrm{FeCl}_{3}(0.1 \%)$. The absorbance of the reaction mixture was then measured at $700 \mathrm{~nm}$ against the blank sample (without extract). Ascorbic acid and butylated hydroxyl toluene solutions were used as positive controls. Increase in absorbance of the reaction mixture indicated increased reducing power.

2.5.4. Nitric Oxide (NO) Radical Scavenging Activity Assay. Nitric oxide scavenging activity was determined using the method described by Ebrahimzadeh et al. [29]. Two millilitres $(2 \mathrm{~mL})$ of $10 \mathrm{mM}$ sodium nitroprusside dissolved in $0.5 \mathrm{~mL}$ phosphate-buffered saline ( $\mathrm{pH} 7.4$ ) was mixed with $0.5 \mathrm{~mL}$ of plant extract or vitamin $C$ or rutin at various concentrations $(0.025,0.05,0.1,0.2$, and $0.5 \mathrm{mg} / \mathrm{mL})$. The resulting mixture was incubated at $25^{\circ} \mathrm{C}$ for 2.5 hours. After incubation, 0.5 $\mathrm{mL}$ of the reaction mixture was taken and mixed with $0.5 \mathrm{~mL}$ of Griess reagent (containing $1.0 \mathrm{~mL}$ of $0.33 \%$ sulfonic acid in $20 \%$ glacial acetic acid) and was incubated for 10 minutes at room temperature with $1 \mathrm{~mL}$ of naphthylethylene diamine dichloride $(0.1 \% w / v)$. The mixture was incubated at room temperature for 30 minutes, and the absorbance measured at $540 \mathrm{~nm}$. The inhibition of nitric oxide radical was calculated as

$$
[(\text { Abs }(\text { control })-\text { Abs }(\text { sample })) /(\text { Abs }(\text { control }))] \times 100 \text {. }
$$

where Abs (control) is the absorbance of $\mathrm{NO}$ radical+methanol and Abs (sample) is the absorbance of NO radical+sample extract or standard.

2.5.5. Hydrogen Peroxide Scavenging Activity Assay. The ability of the plant extract to scavenge hydrogen peroxide was determined by the method of Kibiti and Afolayan [3]. Two millilitres $(2 \mathrm{~mL})$ of plant extracts prepared at various concentrations $(0.025,0.05,0.1,0.2$, and $0.5 \mathrm{mg} / \mathrm{mL})$ was mixed with $6 \mathrm{~mL}$ of $4 \mathrm{mM} \mathrm{H}_{2} \mathrm{O}_{2}$ solution in phosphate buffer $(0.1 \mathrm{M} \mathrm{pH}$ 7.4). The mixture was incubated for 10 minutes at room temperature. The absorbance of the solution was measured at $230 \mathrm{~nm}$ against the blank solution containing the plant extracts without $\mathrm{H}_{2} \mathrm{O}_{2}$. The result obtained was compared with standard ascorbic acid. Percentage inhibition of $\mathrm{H}_{2} \mathrm{O}_{2}=[($ Abs (control) - Abs (sample $)) /($ Abs (control) $\left.)\right]$ $\times 100$, where $\mathrm{Abs}$ (control) is the absorbance of the control and Abs (sample) is the absorbance of the extracts/standard.

2.6. Data Analysis. All data were expressed as mean \pm standard deviation (SD) of three replications. One-way analysis of variance (ANOVA) was used to compare the differences between the cultivated and wild A. amatymbica samples. Where applicable, data were subjected to statistical analysis using SAS (Statistical Analysis System) package. Mean separation was done using Fischer's LSD where the data showed significance $(p<0.05)$. The concentrations required to attain $50 \%$ radical scavenging activity $\left(\mathrm{IC}_{50}\right)$ was determined from regression lines with $95 \%$ confidence level.

\section{Results}

3.1. Quantification of Phytochemicals. Phytochemical constituents of wild and cultivated A. amatymbica revealed the presence of tannins, saponins, alkaloids, proathocyanidins, flavonoids, flavonols, and total phenolics (Table 1). The phytochemicals obtained from the plant extracts varied greatly among the three solvents, in both wild and cultivated plants. Wild and cultivated plants showed a significant difference $(p<0.05)$ in tannin content for both acetone and methanol extracts but not in water extracts. The methanol and acetone extracts of wild and cultivated plants showed a significant difference $(p<0.05)$ in the alkaloid contents except in water extracts. Saponin contents in both wild and cultivated extracts of A. amatymbica showed a significant difference $(p<0.05)$ in all solvents. Methanol and water extracts of wild plants showed a significantly higher $(p<0.05)$ saponin content of (34.47 and $12.80 \mathrm{mg} / \mathrm{g}$, respectively) except in acetone extracts. The total phenolic content of wild and cultivated plants showed a significance difference $(p<0.05)$ in acetone and water extracts only. Methanol and water extracts of cultivated plants had higher total phenolic content of 98.44 and $66.46 \mathrm{mg} / \mathrm{g}$, respectively. Wild A. amatymbica extracts exhibited significantly higher $(p<0.05)$ total flavonols, flavonoids, and proanthocyanidin contents in all solvents compared to cultivated plants.

3.2. Ferric Antioxidant Reducing Power (FRAP). The reducing power of the wild and cultivated A. amatymbica from the three solvent extracts and standard drugs is shown in 
TABle 1: Phytochemical constituents of acetone, water, and methanol extracts from wild and cultivated Alepidea amatymbica rhizomes.

\begin{tabular}{lcccccc}
\hline \multirow{2}{*}{ Phytochemical constituents } & \multicolumn{2}{c}{ Extracts of wild A. amatymbica } & \multicolumn{3}{c}{ Extracts of cultivated A. amatymbica } \\
& Acetone & Methanol & Water & Acetone & Methanol & Water \\
\hline Tannin (mg/g) & $59.70^{\mathrm{a}} \pm 0.417$ & $62.40^{\mathrm{a}} \pm 0.721$ & $11.67^{\mathrm{c}} \pm 0.304$ & $39.70^{\mathrm{b}} \pm 0.143$ & $41.30^{\mathrm{b}} \pm 0.21$ & $9.80^{\mathrm{c}} \pm 0.18$ \\
Alkaloids (\%) & $16.12^{\mathrm{a}} \pm 0.03$ & $17.80^{\mathrm{a}} \pm 0.015$ & $14.70^{\mathrm{b}} \pm 0.04$ & $12.39^{\mathrm{c}} \pm 0.02$ & $11.98^{\mathrm{c}} \pm 0.14$ & $13.21^{\mathrm{b}} \pm 0.06$ \\
Saponin (\%) & $10.97^{\mathrm{c}} \pm 0.102$ & $34.47^{\mathrm{a}} \pm 0.87$ & $12.80^{\mathrm{b}} \pm 0.66$ & $12.0^{\mathrm{b}} \pm 0.35$ & $12.20^{\mathrm{b}} \pm 0.30$ & $10.81^{\mathrm{c}} \pm 0.82$ \\
Total phenolics (mg GAE/g) & $117.8^{\mathrm{a} \pm 8.45}$ & $97.81^{\mathrm{b}} \pm 7.71$ & $32.30^{\mathrm{d}} \pm 3.43$ & $67.01^{\mathrm{c}} \pm 3.27$ & $98.44^{\mathrm{b}} \pm 6.08$ & $66.46^{\mathrm{c}} \pm 5.29$ \\
Total flavonols (mg QE/mg) & $24.13^{\mathrm{c}} \pm 7.1$ & $68.67^{\mathrm{a}} \pm 8.13$ & $18.32^{\mathrm{d}} \pm 0.30$ & $21.91^{\mathrm{d}} \pm 2.56$ & $58.97^{\mathrm{b}} \pm 5.91$ & $10.61^{\mathrm{e}} \pm 1.14$ \\
Total flavonoids (mg QE/mg) & $97.33^{\mathrm{a}} \pm 7.20$ & $99.09^{\mathrm{a}} \pm 7.20$ & $55.01^{\mathrm{c}} \pm 6.51$ & $59.66^{\mathrm{c}} \pm 0.17$ & $67.32^{\mathrm{b}} \pm 4.1$ & $48.65^{\mathrm{d}} \pm 7.74$ \\
Total proanthocyanidin (mg CE/g) & $262.7^{\mathrm{b}} \pm 4.52$ & $325.7^{\mathrm{a}} \pm 8.70$ & $244.4^{\mathrm{c}} \pm 6.28$ & $144.7^{\mathrm{d}} \pm 4.51$ & $243.4^{\mathrm{c}} \pm 5.30$ & $153.4^{\mathrm{d}} \pm 1.37$ \\
\hline
\end{tabular}

Data are expressed as means of triplicate $(n=3$, mean \pm standard deviation); means with different letters or superscripts are significantly different $(\mathrm{a}>\mathrm{b}>\mathrm{c})$. Means with different superscripts or letters are significantly different $(p<0.05)$ in the different plants (wild and cultivated) but similar extracts or solvents. GAE: gallic acid equivalent; QE: quercetin equivalent; CE: catechin equivalent.

Figure 1. The reducing power of the solvent extracts on ferric to ferrous gradually increased with increase in concentration. The reducing capacity of methanol extracts of wild and cultivated plants within a concentration showed no significant difference $(p>0.05)$ in all concentrations tested. Acetone extracts of the wild plants had a significantly higher mean $(p<0.05)$ reducing power than acetone extracts of the cultivated plants. Significantly higher $(p<0.05)$ reducing powers were also observed in water extracts of the wild plants at all concentrations assayed.

3.3. Hydrogen Peroxide Inhibition. The hydrogen peroxide radical inhibition activities of wild and cultivated $A$. amatymbica are presented in Figure 2. There was a concentrationdependent increase in inhibition in the extracts assayed. The methanol extracts of both wild and cultivated plants showed a significant difference $(p<0.05)$ at all concentrations. The methanol extract of the wild plants showed significantly higher mean $(p<0.05)$ radical inhibition at all concentrations. There was also a significant difference $(p<0.05)$ in radical inhibition by the acetone extracts of the cultivated and wild plant at all concentrations except at $0.5 \mathrm{mg} / \mathrm{mL}$. Acetone extracts of the wild plants had significantly higher $(p<0.05)$ scavenging activity of $14.15,31.04$, and $34.51 \%$ at $0.025,0.05$, and $0.1 \mathrm{mg} / \mathrm{mL}$, respectively, except at $0.2 \mathrm{mg} / \mathrm{mL}$. The water extracts of the wild plants had significantly higher radical inhibition compared to water extracts of the cultivated plants.

3.4. ABTS Radical Scavenging Activity. The results of ABTS radical scavenging activity of wild and cultivated $A$. amatymbica at various concentrations are shown in Figure 3. There was a concentration-dependent response in this assay. All the solvent extracts showed great ABTS radical scavenging activity at very low concentrations. There was no significant difference $(p>0.05)$ in radical scavenging activity in the methanol extracts of the wild and cultivated plants except at a concentration of $0.025 \mathrm{mg} / \mathrm{mL}$. Methanol extracts of the wild plants had a significantly higher $(p<0.05)$ radical scavenging activity of $91.55 \%$ at $0.025 \mathrm{mg} / \mathrm{mL}$. The acetone extracts of both wild and cultivated plants showed no significant difference $(p>0.05)$ at all concentrations except at
$0.025 \mathrm{mg} / \mathrm{mL}$. Acetone extracts of the cultivated plants showed significantly higher ABTS inhibition of $88.45 \%$. A significant difference $(p<0.05)$ was observed in the water extracts of wild and cultivated plants at all concentrations but not at $0.5 \mathrm{mg} / \mathrm{mL}$. Water extracts of the wild plants exhibited higher radical scavenging activity of 79.96, 89.37, 93.51, and $94.74 \%$ at $0.025,0.05,0.1$, and $0.2 \mathrm{mg} / \mathrm{mL}$ concentrations, respectively, compared to those of the cultivated plants.

3.5. DPPH Radical Scavenging Activity. The DPPH radical scavenging activity of the different solvent extracts of wild and cultivated A. amatymbica is compared to that of known antioxidants (vitamin $\mathrm{C}$ and $\mathrm{BHT}$ ), and their respective concentrations and are presented in Figure 4. The DPPH radical scavenging potential in all solvent extracts and $\mathrm{BHT}$ significantly increased with increasing concentrations in both wild and cultivated plants. The methanol extracts of wild and cultivated plants showed a significant difference $(p<0.05)$ at all concentrations except at $0.2 \mathrm{mg} / \mathrm{mL}$ and $0.5 \mathrm{mg} / \mathrm{mL}$. The methanol extract of the cultivated plants exhibited a higher radical scavenging activity of $89.4,90.77$ and $92.05 \%$ at $0.025,0.05$ and $0.1 \mathrm{mg} / \mathrm{mL}$ concentrations, respectively. No significant difference $(p>0.05)$ was observed on the DPPH radical scavenging activity of acetone extracts of the wild and cultivated plants. The water extracts of wild and cultivated plants showed a significance difference $(p<0.05)$ at all concentrations. Water extracts of cultivated plants showed a significantly higher $(p<0.05)$ radical scavenging activity.

3.6. Nitric Oxide (NO) Inhibition. The inhibitory effect of various extracts of wild and cultivated A. amatymbica comparable to the standards (BHT and vitamin $\mathrm{C}$ ) is presented in Figure 5. Extracts from three solvents demonstrated a strong scavenging activity against nitric oxide radical compared to standards. There was no significant difference $(p>0.05)$ in the radical scavenging activity of the methanol extracts of wild and cultivated plants at all concentrations excepts at $0.025 \mathrm{mg} / \mathrm{mL}$. Methanol extracts of the wild plants had a significantly higher $(p<0.05)$ scavenging activity of $67.7 \%$ compared to methanol extracts of the cultivated plants. The acetone extracts of wild and cultivated plants showed a significant difference $(p<0.05)$ in radical scavenging activity 


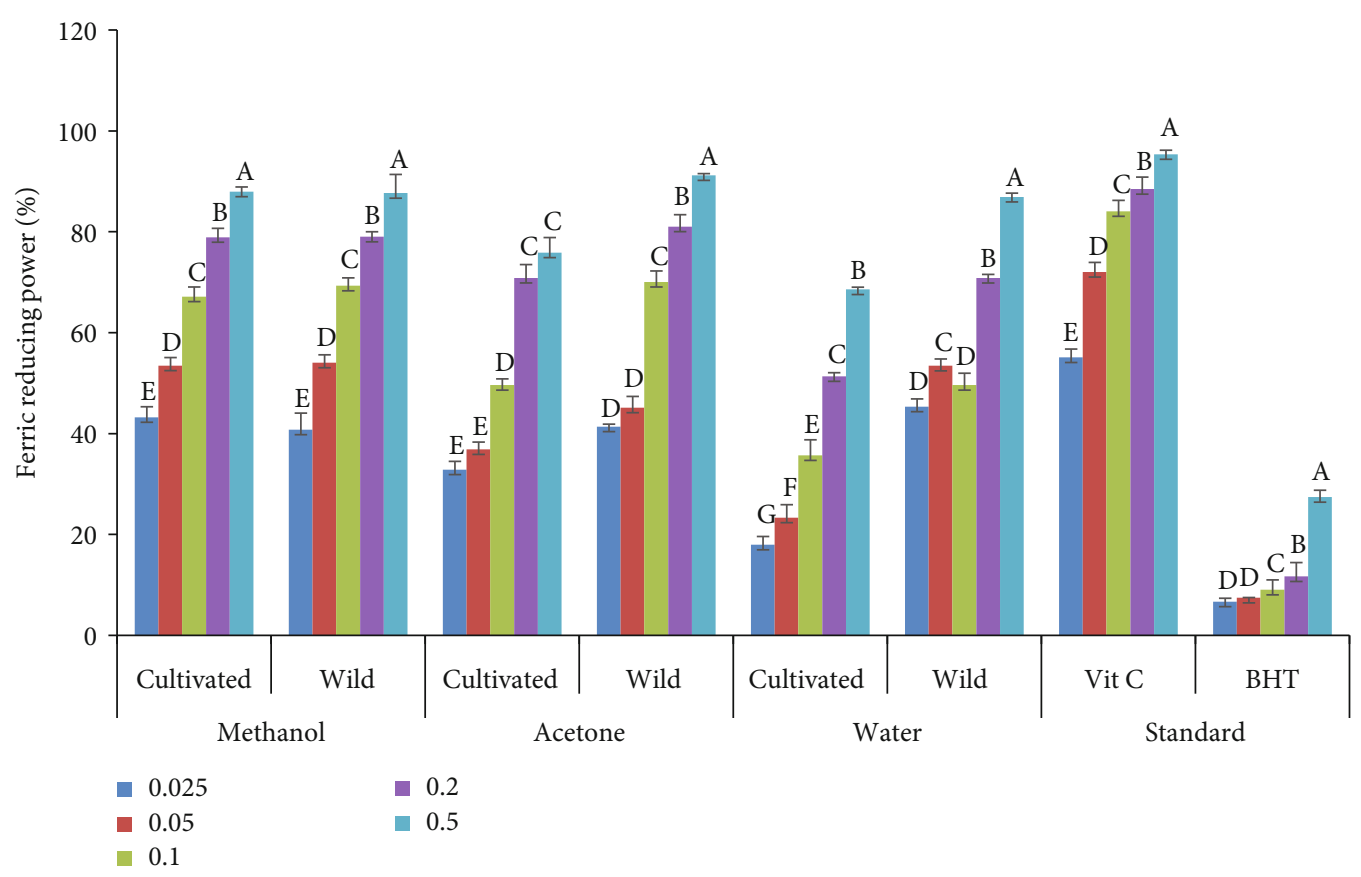

FIgURe 1: Reducing power of acetone, methanol, and water extracts of wild and cultivated A. amatymbica. Bar graphs with different letters within the same solvents are significantly different $(p<0.05)$; wild = wild A. amatymbica; cultivated = cultivated A. amatymbica.

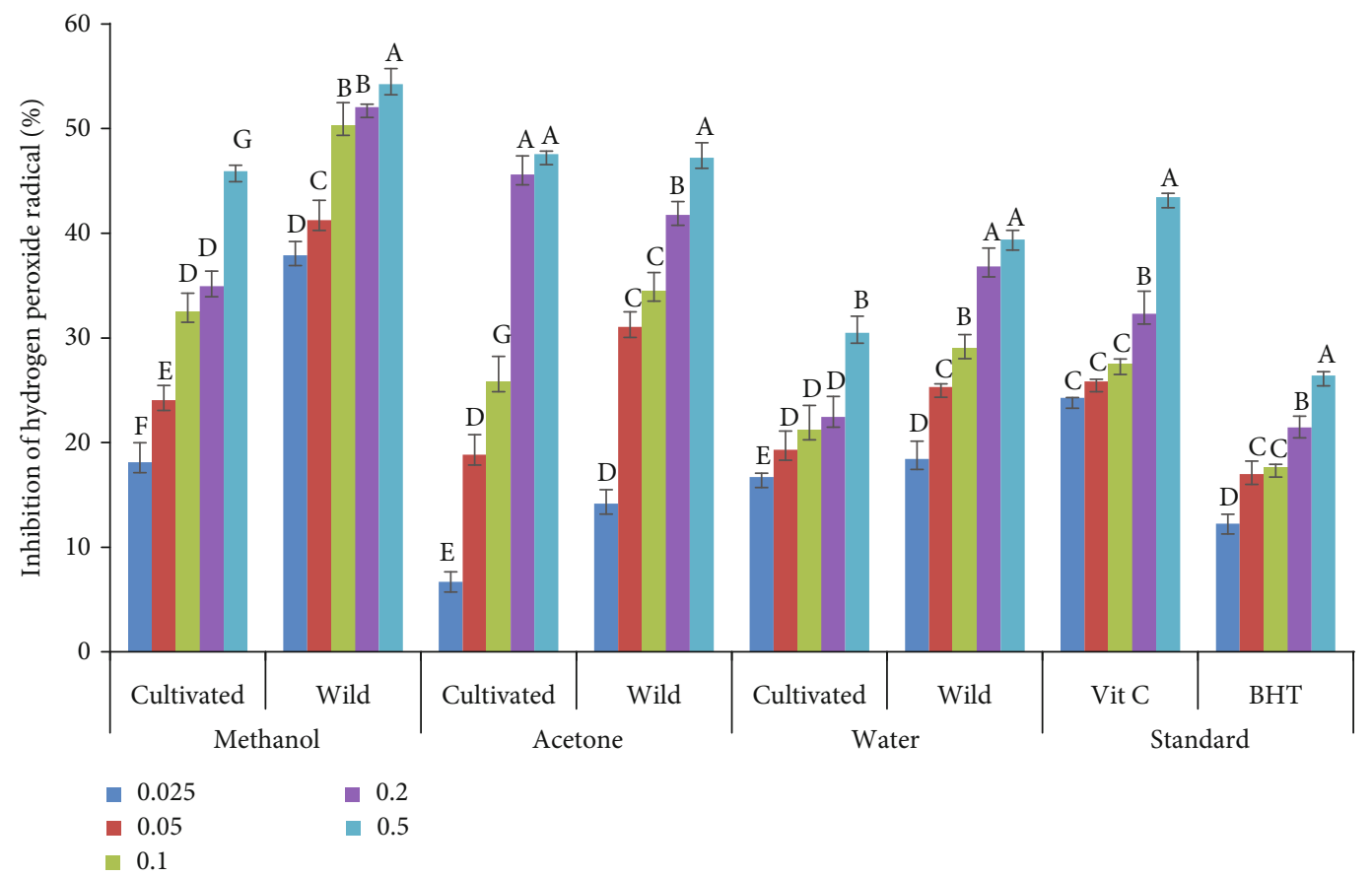

FIgURE 2: Hydrogen peroxide radical scavenging activities of acetone, methanol, and water extracts of wild and cultivated extracts of $A$. amatymbica rhizome. Bars with different superscript letters within the same solvent are significantly different $(p<0.05)$; wild $=$ wild $A$. amatymbica; cultivated $=$ cultivated $A$. amatymbica.

at all concentrations assayed. Acetone extracts of the wild plants had a significantly higher mean inhibition at all concentrations. Higher significant $(p<0.05)$ inhibition was also observed in the water extracts of wild plants compared to cultivated plants at all concentrations.
3.7. Effects of Wild and Cultivated A. amatymbica Extracts and Standards (BHT and Vitamin C) at Their Respective Concentrations That Scavenged 50\% (IC $\left.{ }_{50}\right)$ of the Radicals. The inhibition of ferric reducing power, hydrogen peroxide, ABTS, and DPPH by all extracts and standards at their 


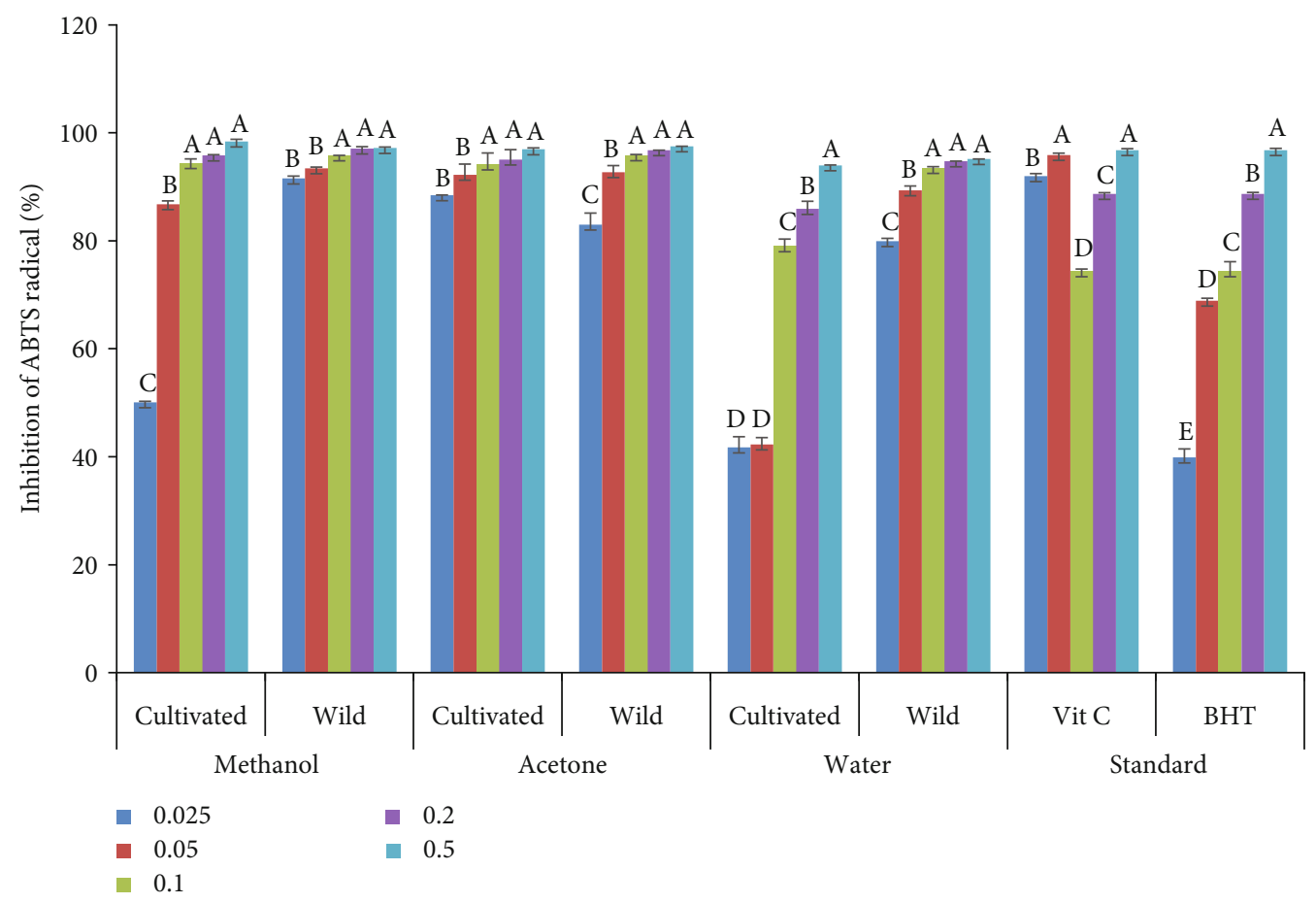

FIGURE 3: ABTS radical scavenging activity of acetone, methanol, and water extracts from wild and cultivated extracts of A. amatymbica rhizome obtained from different solvents. Bar graphs with different superscript letters within the same solvent are significantly different $(p<0.05)$; wild = wild A. amatymbica; cultivated = cultivated A. amatymbica .

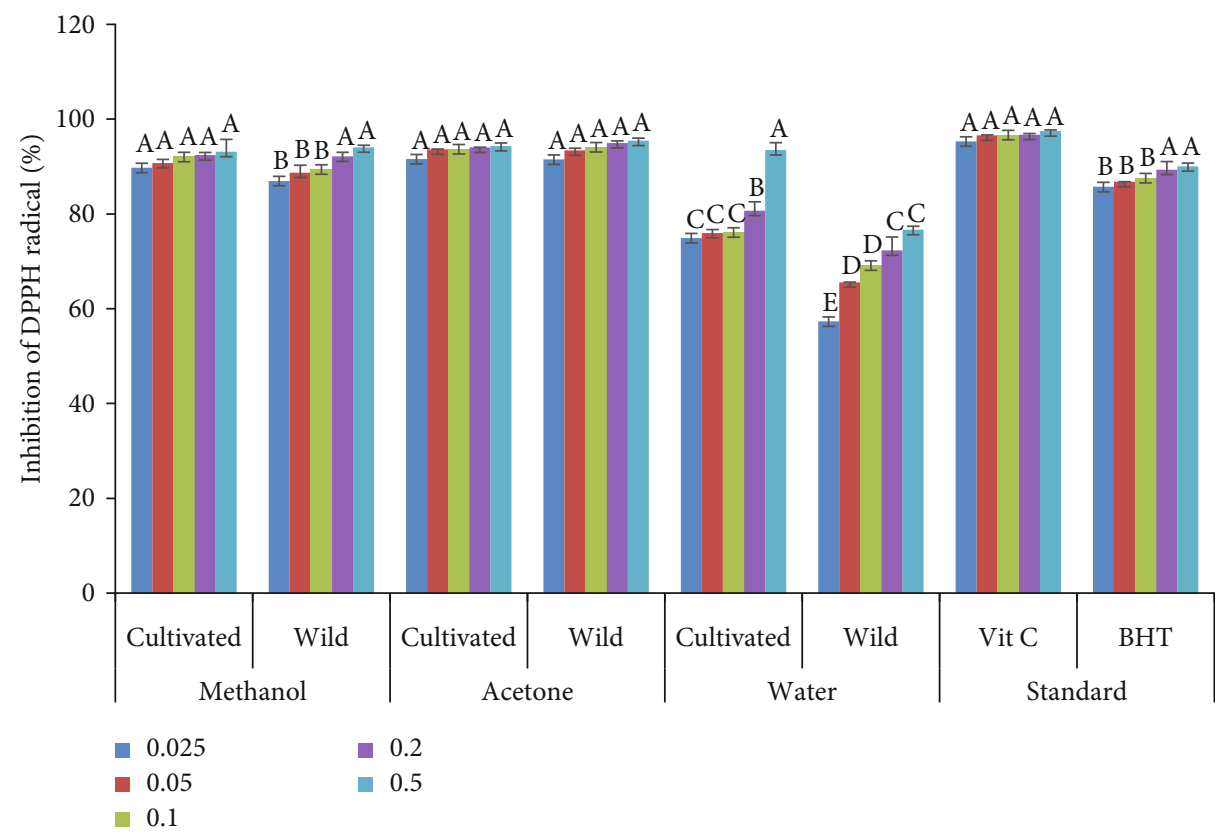

FIGURE 4: DPPH radical scavenging activity of acetone, methanol, and water extracts of wild and cultivated A. amatymbica. Bars with different letters within the same solvents are significantly different $(p<0.05)$.

respective concentrations that scavenged $50 \%\left(\mathrm{IC}_{50}\right)$ of their radicals is shown in Table 2. The ferric reducing power scavenging activity of the extracts and the standard drugs based on the $\mathrm{IC}_{50}$ was in the decreasing order: vitamin $\mathrm{C}$ (standard) > wild (water) > wild (methanol) > cultivated (methanol) $>$ wild (acetone) $>$ cultivated (acetone) $>$ cultivated (water) $>$ BHT (standard). The wild plants showed a better reducing $\mathrm{IC}_{50}$ than the cultivated plants. The hydrogen peroxide scavenging activity as recorded from the $\mathrm{IC}_{50}$ values is in the following order: wild 


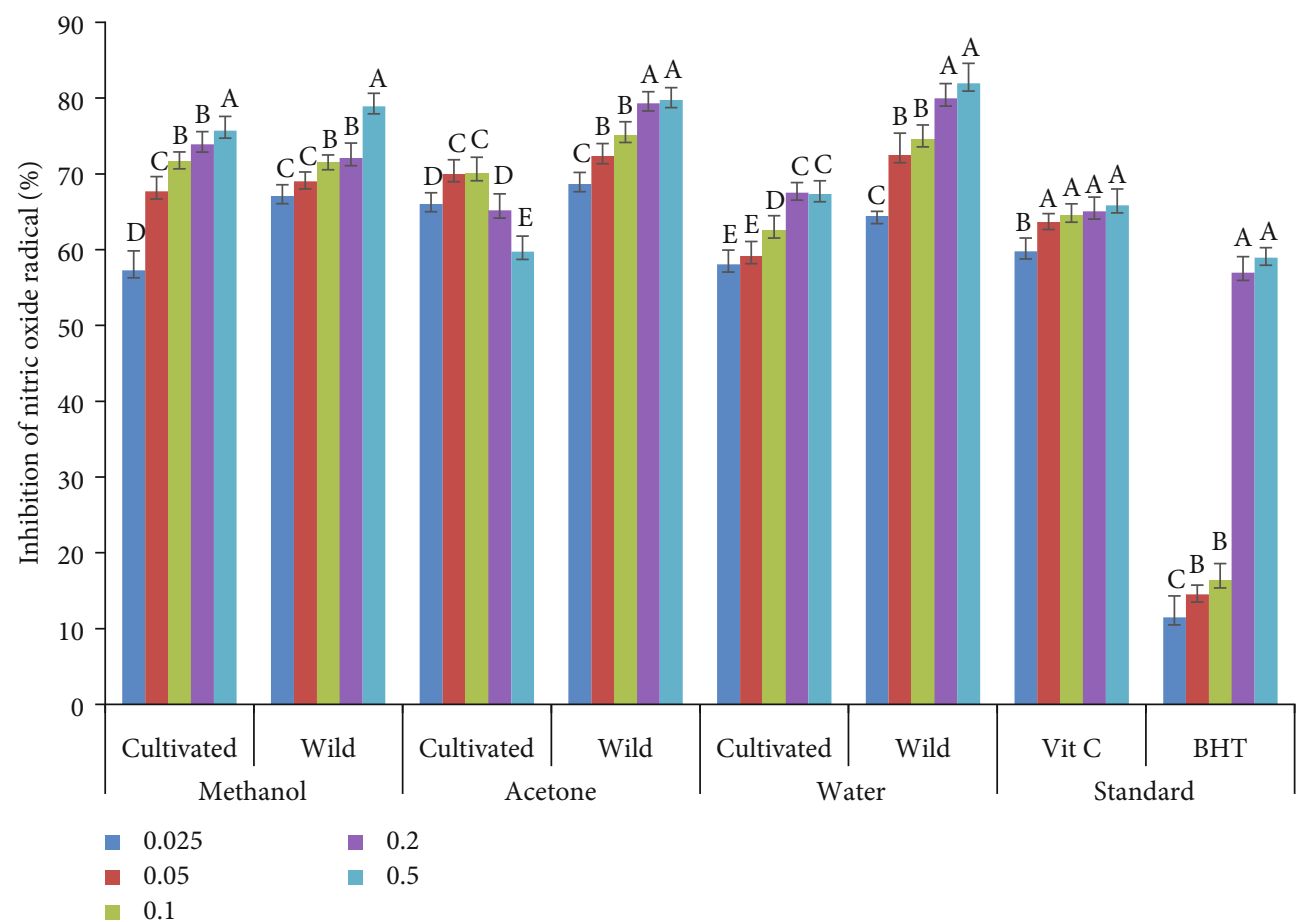

FIGURE 5: Nitric oxide radical scavenging activity of the acetone, methanol, and water extracts from wild and cultivated A. amatymbica rhizomes. Bar graphs with different letters within the same solvents are significantly different $(p<0.05)$. Wild $=$ wild A. amatymbica; cultivated $=$ cultivated A. amatymbica .

(methanol) $>$ wild (acetone) $>$ cultivated (acetone) $>$ vitamin $\mathrm{C}($ standard $)>$ wild $($ water $)>$ cultivated $($ methanol $)>$ cultivated (water) $>$ BHT (standard). However, water extracts of the cultivated plants and BHT showed no activity against hydrogen peroxide.

The $\mathrm{IC}_{50}$ values showed ABTS radical scavenging potential of all the extracts, and the standards were in the following order: vitamin C (standard) > wild (methanol) > cultivated (acetone) $>$ wild (acetone) $>$ wild (water) $>$ cultivated (methanol) $>$ cultivated (water) $>$ BHT (standard). Methanol extracts of the wild plants, acetone extracts of cultivated plants, and vitamin $\mathrm{C}$ showed the higher potential of ABTS as evaluated by the $\mathrm{IC}_{50}$ which was greater than the least concentration evaluated. Methanol extracts and acetone extracts of the wild plants and acetone extracts of the cultivated plants showed higher potential of $\mathrm{DPPH}$ with $\mathrm{IC}_{50}$ which was greater than the least concentration evaluated. The DPPH radical scavenging potential followed this trend: $\mathrm{BHT}>$ wild (methanol) $>$ cultivated (acetone) $>$ wild (acetone) $>$ cultivated (water), wild (water) > vitamin C. The acetone extracts of the cultivated plants showed no activity on the scavenging of the nitric oxide. The nitric oxide radical scavenging potential of all the extracts and the standards based on the $\mathrm{IC}_{50}$ was in the decreasing order: BHT, wild (methanol) $>$ wild (water) $>$ cultivated (water) $>$ wild (acetone) $>$ cultivated (methanol) $>$ vitamin $\mathrm{C}>\mathrm{BHT}>$ cultivated (acetone).

\section{Discussion}

Phytochemical contents varied greatly among the three solvents in both wild and cultivated plants. This is an indica- tion that the solvents have different extracting abilities for phytochemicals. It was observed that the phytochemical constituents in the wild plants were higher than those in the cultivated plants. The harsh seasonal variations may explain the differences in the concentration of bioactive compounds between the wild and cultivated A. amatymbica [30, 31]. The differences may be due to agronomic practices which may influence the environmental conditions, nutrients in the soil, and other parameters that may alter the growth rate and metabolic activity of the plant [32]. Arjamand et al. [23], in their studies on wild and cultivated Satureja bachtiarica, reported agromorphological divergence which may have contributed to great variability in the value of the essential oil phytochemical constituents of the plant.

In this research, quantitative variability in the flavonoid, tannin, flavonol, and proanthocyanidin contents of the wild and cultivated $A$. amatymbica may be related to differences in geographical locations, climatic conditions, soil type, and natural or anthropogenic disturbances. It was previously reported that the wild state of the plant is usually in a shady and moist habitat but the cultivated plant may be inconsistently shaded and other environmental conditions may not be adequately simulated unlike the ones in the wild; hence there may be phytochemical variations [31] as shown in the results of this research. According to Ashashri et al. [33] and Tajalli et al. [34], the exposure of plants to harsh environmental conditions including insects and infections is known to enhance the productions of flavonols and flavonoids. These phytochemicals are for self-protection. Hence, significantly higher concentrations of flavonoids and flavonols were observed in wild A. amatymbica. Lower concentrations of 


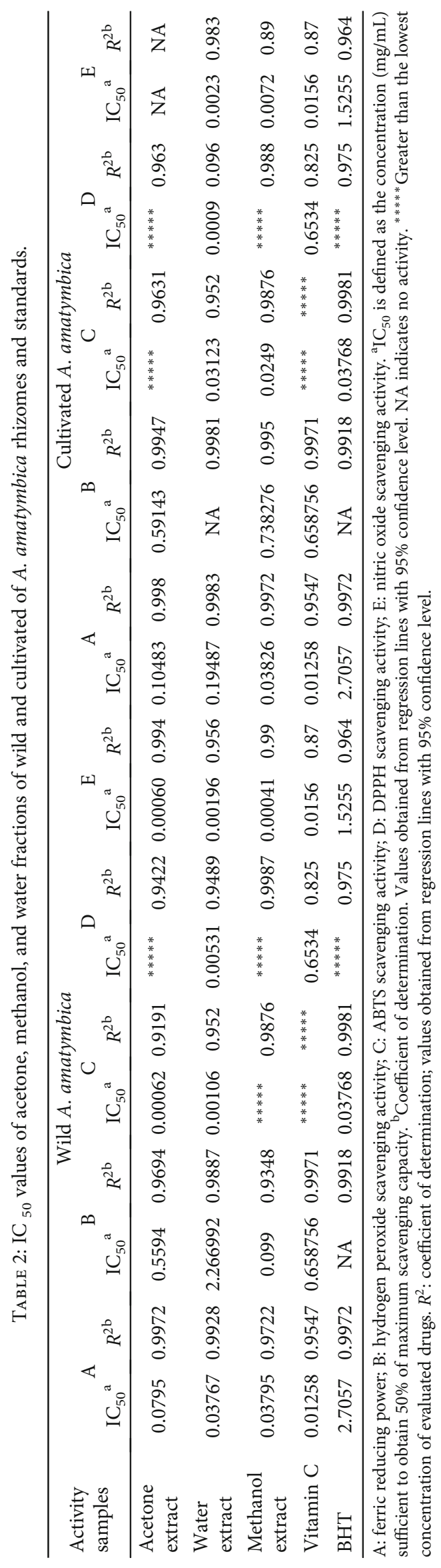


flavonols, flavonoids, tannins, and flavonoids in cultivated plants might be due to the plants being unable to produce desired bioactive compounds under controlled conditions. Similar results were also reported by Sefidkon et al. [35], who observed that cultivated plants produced lower levels of secondary metabolites due to monoculture cultivation conditions. Several studies have reported that majority of pharmacologically important compounds of plant origin are products of defense to protect plants against stress, insects, herbivores, and diseases [16-18]. The presence of flavonoids in both wild and cultivated plants may show the ability of this plant to scavenge free radicals [36]. The higher content of proanthocyanidin observed in this study may validate the claim of medicinal plant users about antihypertensive properties of A. amatymbica which was also reported by Wintola and Afolayan [1].

The nonsignificant difference in alkaloid and tannin contents observed in the water extracts of the wild and cultivated plants might be due to the polarity of solvent used; hence, the significant difference observed in acetone and methanol extracts of wild and cultivated plants may depend on the ability of the solvents to extract some key constituents. (Umpathy et al. [37]). The variation in phytochemical as shown in Table 2, thus, confirmed that variation between wild and cultivated plants may be due to the influence of agronomic parameters such as shading or sunlight exposure and water supply which had impact on chemical composition. The findings of this study were in line with Ahmed et al. [38] in which bioactive compounds from herbal medicine may be affected by physiological response (circadian rhythm and phenology) of plants and agronomic conditions. It has also been reported that growing conditions, such as warm weather, increase the synthesis of secondary metabolites but wet weather conditions can inhibit alkaloid production in many species [19]. Alkaloids have been used medically as analgesic and antiseptic [39]. The presence of alkaloid in both wild and cultivated A. amatymbica shows that the plant could be a potential source of antispasmodic, antimalarial, antiseptic, and antibacterial agents [40]. This could explain the use of A. amatymbica by traditional healers for the treatment of the above ailments. The presence of tannins in wild and cultivated $A$. amatymbica makes the plant a good source of tannin and could be useful for the prevention of cancer as well as treatment of inflamed ulcerated tissue. It can also act as a natural antibiotic by preventing lipid peroxidation $[41,42]$.

The significantly higher phenolic content in the methanol and water extracts of cultivated A. amatymbica might indicate a certain stress parameter that may not be justified in this research. However, it may have been attributed to growing A. amatymbica outside its habitat. Similar results were also obtained by Soriano-Melgar et al. [43], who demonstrated that domestication process and cultivation increased some phytochemicals and antioxidant activities of Turnera diffusa. Willd. ex Schult. It has been reported that phenolics inactivate iron ions by chelating and additionally suppressing the superoxide-driven Fenton reaction, which is believed to be the most important source of reactive oxygen ions [44]. The results from this study suggest that high phenolic content in cultivated A. amatymbica could have pharmacological effects which may also be attributed to agromorphological divergence. These results also suggest that relocating these plants from the wild to nursery did not result in the loss of phenols. Therefore, results further confirm that the similarity in some of phytochemicals between the wild and cultivated plants may be helpful for the domestication of A. amatymbica by medicinal plant users.

The nonsignificant difference observed in ferric reducing power of the methanol extracts of wild and cultivated A. amatymbica might be to the high amount of phenolic content in the plants. Significantly higher ferric reducing power observed in acetone and water extracts of wild A. amatymbica at all concentrations may be due to the higher content of phytochemical in the wild plants. Several authors have reported that antioxidant activity expression is a consequence of the synergism between different phytochemical compounds and can be attributed to constituents $[27,45,46]$. The significant influence of environmental conditions on the phytochemicals and consequently to ferric reducing power of wild and cultivated A. amatymbica may be indicating the important role played by the environment, ultraviolet (UV) radiation, temperature, water stress, and mineral nutrient availability [47]. Amounts of phytochemical constituents found in both wild and cultivated A. amatymbica correlated with antioxidant activity which confirms that they are contributing factors towards its antioxidant properties [48].

Hydrogen peroxide is an important reactive oxygen species (ROS) which has the ability to penetrate biological molecules and convert toxic to hydrophilic and breakdown to hydroxyl radical in the cell. However, the hydroxyl radical generated in the cell has been reported to induce breakage in DNA strand and chemical changes in the deoxyribose and nitrogenous bases; hence, hydroxyl radicals generated are degraded by the liver [49]. This research revealed that wild A. amatymbica exhibited a high percentage of hydrogen peroxide radical scavenging activity and this may be attributed to the higher flavonol, flavonoid, and proanthocyanidin contents in the wild plant compared to cultivated ones. This result is in agreement with the findings of Motlhanka [46], who reported that the cultivation has reduced antioxidant activity. It has been reported that drought and salt stress in a natural environment cause production of reactive oxygen species (ROS) within the plant resulting in an increased level of secondary metabolites, including phytochemicals. Hence, wild plants exhibited higher hydrogen peroxide radical inhibition [50]. The reduction in the antioxidant efficacy of the cultivated A. amatymbica could be a reason to depend more on the wild species for therapy.

Significance difference in $\mathrm{ABTS}^{+}$inhibition observed in acetone and methanol extracts of wild A. amatymbica and methanol extracts of cultivated $A$. amatymbica at $0.025 \mathrm{mg} / \mathrm{mL}$ may be due to the lesser phytoconstituent content in the cultivated plants. This study reflected the capacity of wild and cultivated A. amatymbica to inhibit or quench free radicals. The ABTS radical scavenging potential exhibited by wild plant extracts could be attributed to polyphenolic compounds as earlier shown in the results. This agrees with several reports of plants which show antioxidant activity with ABTS $[22,25,51]$. The ability of the extracts to 
scavenge free radicals supports the folkloric use of the plant as a useful therapeutic agent for treating radical-related pathological damages. Also, it confirms the fact that cultivation of A. amatymbica did not affect the ability of the plant to inhibit free radicals.

The scavenging ability of the stable DPPH radical is widely used in evaluating the free radical scavenging ability of various compounds [25]. It was observed that DPPH radical scavenging potential in all solvent extracts and $\mathrm{BHT}$ significantly increased with increasing concentrations in both wild and cultivated plants. The research revealed that water extracts of the cultivated A. amatymbica exhibited significantly higher DPPH radical inhibition which may be due to the significantly higher phenolic compounds present in the water extracts of the cultivated plants. Similar results were reported by Masondo et al. [52] about the potency of cultivated Bowiea volubilis in traditional medicine. The similarity in DPPH radical scavenging activity of acetone extracts of wild and cultivated plants in this study could be attributed to the presence of other bioactive agents capable of donating electrons. This result indicates the ethnopharmacological potential of cultivated A. amatymbica in traditional medicine.

Nitric oxide is also an important cellular signaling molecule needed in low amounts to protect some vital organs in the human body, especially the liver and heart, from ischemic damage and hypertension. However, the overproduction of this molecule may cause inflammation and pathogenesis of various human diseases such as cardiovascular diseases which may be detrimental to human health. Higher nitric oxide observed in wild $A$. amatymbica might be due to the fact that the therapeutic properties of herbal medicines are biosynthesized by plants under particular conditions of stress and competition in their natural environments [53]. Hence, extracts of the cultivated plants had a lower nitric oxide inhibition activity. It was also observed that extracts of wild and cultivated plants showed good nitric oxide scavenging activity as compared to those of the standards. The nitric oxide inhibiting ability of the plant extracts could partially justify the use of wild plants in the treatment of oxidativeinduced ailments due to its higher scavenging activity.

\section{Conclusion}

There were significant differences among compositions and antioxidant activities of studied extracts. The wild plants exhibited superior levels of phytochemical and antioxidant activities than cultivated $A$. amatymbica. Even though cultivated plants of $A$. amatymbica showed lower levels of proanthocyanidin, total flavonols, total flavonoids, alkaloids, and tannin, this however showed that the potential of the plant has been used in an antioxidant agent as the $\mathrm{IC}_{50}$ showed activity at the lowest concentrations tested. Therefore, this $\mathrm{IC}_{50}$ gives an indication that cultivated A. amatymbica can be effectively used in traditional medicine rather than relying on the rhizome from the wild populations alone. Based on the presented results, the rareness of natural antioxidant medicinal plants due to the cost and unavailability of the wild plants could be overcome by using cultivated species. Domestication of these wild plants coupled with extensive qualitative profiling to validate consistency in phytochemical composition can reduce the pressure on the wild populations.

\section{Data Availability}

The data used to support the findings of this study are included within the article or manuscript and the information mentioned is also included in the manuscript.

\section{Conflicts of Interest}

The authors declare no conflict of interest.

\section{Authors' Contributions}

Ramatsobane Maureen Mangoale and Anthony Jide Afolayan conceptualised the topic and designed the work. Ramatsobane Maureen Mangoale performed the experiment, collected and analysed the data, visualised the results, and wrote the manuscript. Prof. A.J. Afolayan proofread the paper. All authors read the final manuscript.

\section{Acknowledgments}

The authors are grateful to Govan Mbeki Research and Development Center (GMRDC), University of Fort Hare, and the National Research Fund of the South Africa for financial assistance.

\section{References}

[1] O. A. Wintola and A. J. Afolayan, "Alepidea amatymbica Eckl. \& Zeyh.: A Review of Its Traditional Uses, Phytochemistry, Pharmacology, and Toxicology," Evidence-Based Complementary and Alternative Medicine, vol. 2014, Article ID 284517, 11 pages, 2014.

[2] G. K. Rasineni, D. Siddavattam, and A. R. Reddy, "Free radical quenching activity and polyphenols in three species of Coleus," Journal of Medicinal Plants Research, vol. 2, no. 10, pp. 285291, 2008.

[3] C. M. Kibiti and A. J. Afolayan, "Preliminary Phytochemical Screening and Biological Activities of Bulbine abyssinica Used in the Folk Medicine in the Eastern Cape Province, South Africa," Evidence-Based Complementary and Alternative Medicine, vol. 2015, Article ID 617607, 12 pages, 2015.

[4] L. I. Sowunmi and A. J. Afolayan, "Phytochemical constituents and antioxidant properties of acetone extract of Cleome gynandra (L.) growing in the Eastern Cape, South Africa," African Journal of Traditional, Complementary and Alternative Medicines, vol. 12, no. 3, pp. 1-8, 2015.

[5] W. M. Otang, D. S. Grierson, and R. N. Ndip, "Phytochemical studies and antioxidant activity of two South African medicinal plants traditionally used for the management of opportunistic fungal infections in HIV/AIDS patients," $B M C$ Complementary and Alternative Medicine, vol. 12, no. 1, pp. 12-43, 2012.

[6] S. O. Oyedemi, G. Bradley, and A. J. Afolayan, "In vivo and in vitro antioxidant activities of aqueous stem bark extract of Strychnos henningsii (Gilg)," African Journal of Pharmacology and Pharmacognosy, vol. 4, pp. 70-78, 2010. 
[7] A. Basile, L. Ferrara, M. D. Pezzo et al., "Antibacterial and antioxidant activities of ethanol extract from Paullinia cupana Mart.," Journal of Ethnopharmacology, vol. 102, no. 1, pp. 32-36, 2005.

[8] A. V. Krishnaraj, C. V. Rao, T. V. N. Rao, K. N. Reddy, and G. Trimurtulu, "In vitro and in vivo antioxidant activity of Aphanamixis polystachya bark," American Journal of Infectious Diseases, vol. 5, no. 2, pp. 60-67, 2009.

[9] R. L. Yang, Y. H. Shi, G. Hao, W. Li, and G. W. le, "Increasing oxidative stress with progressive hyperlipidemia in Human: relation between malondialdehyde and atherogenic Index," Journal of Clinical Biochemistry and Nutrition, vol. 43, no. 3, pp. 154-158, 2008.

[10] D. Raimondo, L. V. Staden, W. Foden et al., Red list of South African plants 2009, South African National Biodiversity Institute, Pretoria, 2009.

[11] A. P. Dold and M. L. Cocks, "The trade in medicinal plants in the Eastern Cape Province, South Africa," South African Journal of Science, vol. 98, pp. 589-597, 2002.

[12] R. Wynberg, "A decade of biodiversity conservation and use in South Africa; a tracking progress from the Rio Earth Summit to the Johannesburg World Summit on Sustainable Development," South African Journal of Science, vol. 98, no. 5, pp. 233-243, 2002.

[13] A. Lubbe and R. Verpoorte, "Cultivation of medicinal and aromatic plants for specialty industrial materials," Industrial Crops and Products, vol. 34, no. 1, pp. 785-801, 2011.

[14] M. F. Pfab and M. A. Scholes, "Is the collection of Aloe peglerae from the wild sustainable? An evaluation using stochastic population modelling," Biological Conservation, vol. 118, no. 5, pp. 695-701, 2004.

[15] E. T. Moeng and M. J. Potgieter, "The trade of medicinal plants by muthi shops and street vendors in the Limpopo Province, South Africa," Journal of Medicinal Plants Research, vol. 5, no. 4, pp. 558-564, 2012.

[16] J. Kuzel, N. T. Vydra, M. Vrchotova, and P. Cigler, "Elucidation of pharmacologically active substance in an intact medicinal plants," Journal of Agriculture and Food Chemistry, vol. 57, pp. 7909-7911, 2009.

[17] R. L. Andrew, I. R. Wallis, C. E. Harwood, M. Henson, and W. J. Foley, "Heritable variation in the foliar secondary metabolite sideroxylonal in Eucalyptus confers cross-resistance to herbivores," Oecology, vol. 153, no. 4, pp. 891-901, 2007.

[18] G. Sudha and G. A. Ravishankar, "Involvement and interaction of various signalling compounds on the plant metabolic events during defence response, resistance to stress factors, formation of secondary metabolites and their molecular aspects," Plant Cell, Tissue and Organ Culture, vol. 71, no. 3, pp. 181-212, 2002.

[19] M. W. Bairu, S. O. Amoo, and J. Van Staden, "Comparative phytochemical analysis of wild and in vitro-derived greenhouse- grown tubers, in vitro shoots and callus-like basal tissues of Harpagophytum procumbens," South African Journal of Botany, vol. 77, no. 2, pp. 479-484, 2011.

[20] Q. X. Zheng, H. F. Wu, J. Guo, H. J. Nan, S. L. Chen, and J. S. Yang, "Chemistry and pharmacology," Chinese Herbal Medicine, vol. 5, no. 1, pp. 9-32, 2013.

[21] L. Mucina, M. C. Rutherford, and L. W. Powrie, "Logic of the map: approaches and procedures," in The Vegetation of South Africa, Lesotho and Swaziland, L. Mucina and M. C. Rutherford, Eds., pp. 12-29, SANBI, Pretoria, 2006.
[22] S. A. Oyedemi, O. O. Oyedemi, S. Arowosegbe, and J. A. Afolayan, "Phytochemicals analysis and medicinal plants of hydroalcoholic extract from Curtusia dentata (Burm.F) C.A. Sm stem Bark," International Journal of Molecular Science, vol. 13, pp. 6189-6203, 2013.

[23] H. Arjamand, D. Mazaheri, J. Hadian, N. Majnoon Hossein, and M. Ghorbanpour, "Essential oils composition, antioxidant activities and phenolics content of wild and cultivated Satureja bachtiarica Bunge plants of Yazd origin," Journal of Medicinal Plants, vol. 13, no. 51, pp. 55-65, 2012.

[24] B. O. Mbaebie, H. O. Edeoga, and A. J. Afolayan, "Phytochemical analysis and antioxidant activities of aqueous stem bark extracts of Schotia latifolia. Jacq," Asian Pacific Journal of Tropical Biomedicine, vol. 2, no. 2, pp. 118-124, 2013.

[25] G. A. Otunola and A. J. Afolayan, "Evaluation of polyphenolic contents and some antioxidants properties of aqueous extracts of garlic, ginger, cayenne pepper and their mixture," Journal of Applied Botany and Food Quality, vol. 86, pp. 66-70, 2013.

[26] O. O. Olajuyigbe and A. J. Afolayan, "Phenolic content and antioxidant property of the bark extracts of Ziziphus mucronata Willd. subsp. mucronata Willd," BMC Complementary and Alternative Medicine, vol. 11, no. 1, pp. 130-141, 2011.

[27] O. A. Wintola and A. J. Afolayan, "Phytochemical constituents and antioxidant activities of the whole leaf extract of Aloe ferox Mill," Pharmacognosy Magazine, vol. 7, no. 28, pp. 325-333, 2011.

[28] O. A. Idris, O. A. Wintola, and A. J. Afolayan, "Phytochemical and antioxidant activities of Rumex crispus L. in treatment of gastrointestinal helminths in Eastern Cape Province, South Africa," Asian Pacific Journal of Tropical Biomedicine, vol. 7, no. 12, pp. 1071-1078, 2017.

[29] M. A. Ebrahimzadeh, S. F. Nabavi, and S. M. Nabavi, “Antioxidant activities of methanol extracts of Sambucus ebulis L. flower," Pakistan Journal of Biological Science, vol. 12, no. 5, p. 447, 2009.

[30] B. Ncube, J. F. Finnie, and J. Van Staden, "Seasonal variation in antimicrobial and phytochemical properties of frequently used medicinal bulbous plants from South Africa," South African Journal of Botany, vol. 77, no. 2, pp. 387-396, 2011.

[31] O. Idris, O. Wintola, and A. Afolayan, "Comparison of the proximate composition, vitamins (ascorbic acid, $\alpha$-Tocopherol and retinol), anti-nutrients (phytate and oxalate) and the GCMS analysis of the essential oil of the root and leaf of Rumex crispus L," Plants, vol. 8, no. 3, p. 51, 2019.

[32] M. Govarthanan, R. Rajinikanth, S. Kamala-Kannan, and T. Selvankumar, "A comparative study on bioactive constituents between wild and in vitro propagated Centella asiatica," Journal of Genetic Engineering and Biotechnology, vol. 13, no. 1, pp. 25-29, 2015.

[33] A. Shinde, P. Gahunge, P. Singh, and S. K. Rath, "Yield and phytochemical evaluation of wild and cultivated samples of Ashwagandha," Journal of Biological \& Scientific Opinion, vol. 2, no. 2, pp. 153-157, 2014.

[34] F. Tajalli, K. Malekzadeh, H. Soltanian, J. Janpoor, S. Rezaeian, and H. R. Pourianfar, "Antioxidant capacity of several Iranian, wild and cultivated strains of the button mushroom," Brazilian Journal of Microbiology, vol. 46, no. 3, pp. 769-776, 2015.

[35] F. Sefidkon, L. Sadeghzadeh, M. Teimouri, F. Asgari, and S. H. Ahmadi, "Antimicrobial effects of the essential oils of two Satureja species (S. khuzistanica Jamzad and S. bachtiarica 
Bunge) in two harvesting time," Iran Journal of Medicinal and Aromatic Plants, vol. 23, pp. 174-182, 2007.

[36] S. Sahoo, R. Parida, S. Singh, R. N. Padhy, and S. Nayak, "Evaluation of yield, quality and antioxidant activity of essential oil of in vitro propagated Kaempferia galanga Linn.," Journal of Acute Disease, vol. 3, no. 2, pp. 124-130, 2014.

[37] E. Umpathy, E. J. Ndebia, A. Meeme, P. Adam, P. Menziwa, and B. N. Nkeh-Chungag, "An experimental evaluation of Albu casetosa aqueous extract on the membrane stabilization, protein denaturation and white blood cell migration during acute inflammation," Journal of Medicinal Plants Research, vol. 4, pp. 785-795, 2010.

[38] A. S. Ahmed, L. J. McGaw, E. E. Elgorashi, V. Naidoo, and J. N. Eloff, "Polarity of extracts and fractions of four Combretum (Combretaceae) species used to treat infections and gastrointestinal disorders in southern African traditional medicine has a major effect on different relevant in vitro activities," Journal of Ethnopharmacology, vol. 154, no. 2, pp. 339-350, 2014.

[39] G. A. Otunola, O. B. Oloyede, A. T. Oladiji, and A. J. Afolayan, "Comparative analysis of the chemical composition of three spices - Allium sativum L. Zingiber officinale Rosc. and Capsicum frutescens L. commonly consumed in Nigeria," African Journal of Biotechnology, vol. 9, no. 41, pp. 6927-6931, 2011.

[40] F. Ahmed, M. S. T. Selim, A. K. Das, and S. Chouduri, "Antiinflammatory and antinociceptive activities of Lippia nodiflora Linn," Die Pharmazie-An International Journal of Pharmaceutical Sciences, vol. 59, no. 4, pp. 329-330, 2004.

[41] D. E. Okwu and I. N. Eminike, "Evaluation of phytonutrients and vitamin contents of Citrus fruits," International Journal of Molecular Medicine Advance, vol. 2, pp. 1-6, 2006.

[42] K. Skarbez, Y. Priestley, M. Hoepf, and S. B. Koevary, "Comprehensive review of the effects of diabetes on ocular health," Expert Review of Ophthalmology, vol. 5, no. 4, pp. 557-577, 2014.

[43] L. de Abril Alexandra Soriano-Melgar, L. Alcaraz-Meléndez, L. C. Méndez-Rodríguez, M. E. Puente, F. Rivera-Cabrera, and T. Zenteno-Savín, "Antioxidant and trace element content of damiana (Turnera diffusa Willd) under wild and cultivated conditions in semi-arid zones," Industrial Crops and Products, vol. 37, no. 1, pp. 321-327, 2012.

[44] J. Momeni, J. P. Djialeu Ntchatchoua, Fadimatou, M. T. Akam, and M. B. Ngassoum, "Antioxidant activities of some Cameroonian plants extracts used in the treatment of intestinal and infectious diseases," Indian Journal of Pharmaceutical Sciences, vol. 72, no. 1, pp. 140-144, 2010.

[45] K. W. Lee, Y. J. Kim, H. J. Lee, and C. Y. Lee, "Cocoa has more phenolic phytochemicals and a higher antioxidant capacity than teas and red wine," Journal of Agricultural and Food Chemistry, vol. 51, no. 25, pp. 7292-7295, 2003.

[46] D. M. T. Motlhanka, "Phytochemical and antioxidant analysis of wild and ex-situ cultivated shoots and tubers of Harpagophytum procumbens (Burch) DC ex Meisn from Botswana," Asian Journal of Conservation Biology, vol. 1, no. 2, pp. 8691, 2012.

[47] T. R. Augusto, E. S. S. Salinas, S. M. Alencar, M. A. B. R. D’arce, A. C. . Camargo, and T. M. F. . S. Vieira, "Phenolic compounds and antioxidant activity of hydroalcoholic extracts of wild and cultivated murtilla (Ugni molinae Turcz.)," Food Science and Technology, vol. 34, no. 4, pp. 667-679, 2014.

[48] S. Tavarini and L. G. Angelini, "Stevia rebaudiana Bertoni as a source of bioactive compounds: the effect of harvest time, experimental site and crop age on steviol glycoside content and antioxidant properties," Journal of the Science of Food and Agriculture, vol. 93, no. 9, pp. 2121-2129, 2013.

[49] D. Randriamampionona, B. Diallo, F. Rakotoniriana et al., "Comparative analysis of active constituents in Centella asiatica samples from Madagascar: Application for ex sit conservation and clonal propagation," Fitoterapia, vol. 78, no. 7-8, pp. 482-489, 2007.

[50] N. Jaradat, M. Abualhasan, and I. Ali, "Comparison of AntiOxidant Activities and Exhaustive Extraction Yields between Wild and Cultivated Cyclamen persicum, Malva sylvestris and Urtica pilulifera Leaves," Journal of Applied Pharmaceutical Science, vol. 5, no. 4, pp. 101-106, 2015.

[51] B. E. Omoruyi, G. Bradley, and A. J. Afolayan, "Antioxidant and phytochemical properties of Carpobrotus edulis (L.) bolus leaf used for the management of common infections in HIV/AIDS patients in Eastern Cape Province," BMC Complementary and Alternative Medicine, vol. 12, no. 1, pp. 12-43, 2012.

[52] N. A. Masondo, A. R. Ndhlala, A. O. Aremu, J. van Staden, and J. F. Finnie, "A comparison of the pharmacological properties of garden cultivated and muthi market-sold Bowiea volubilis," South African Journal of Botany, vol. 86, pp. 135-138, 2013.

[53] S. M. A. Zobayed, F. Afreen, and T. Kozai, "Phytochemical and physiological changes in the leaves of St. John's wort plants under a water stress condition," Environmental and Experimental Botany, vol. 59, no. 2, pp. 109-116, 2007. 